\title{
EARLY VERSUS LATE PERCUTANEOUS TRACHEOTOMY IN CRITICALLY ILL PATIENTS: A RETROSPECTIVE SINGLE CENTER OBSERVATIONAL STUDY
}

\author{
Tihana Magdić Turković ${ }^{1}$, Anita Lukić ${ }^{2}$ and Mladen Perić ${ }^{3,4}$ \\ ${ }^{1}$ Department of Anesthesiology and Intensive Care, Sestre milosrdnice University Hospital Center, Zagreb; \\ ${ }^{2}$ Varaždin General Hospital, Department of Anesthesiology, Resuscitation and Intensive Care, Varaždin; ${ }^{3}$ Zagreb \\ University School of Medicine; ${ }^{4}$ Department of Anesthesiology and Resuscitation, Zagreb University Hospital
}

Centre, Zagreb, Croatia

\begin{abstract}
SUMMARY - Despite decades of experience in tracheotomy, there still exists a controversy over its ideal timing. The aim of our study was to compare the impact of early and late percutaneous tracheotomy in terms of their ability to reduce mechanical ventilation duration and length of stay in Intensive Care Unit, as well as the frequency of ventilator-associated pneumonia and mortality rates in tracheotomized patients. This retrospective observational study indicated that early tracheotomy in surgical and neurosurgical patients was associated with a reduced duration of mechanical ventilation and reduced length of stay in Intensive Care Unit, but was unable to reduce the frequency of ventilator-associated pneumonia and mortality. The reason behind the shorter duration of mechanical ventilation and shorter length of stay in Intensive Care Unit in the early tracheotomy arm was shorter duration of mechanical ventilation carried out prior to tracheotomy, while the duration of mechanical ventilation and the length of stay in Intensive Care Unit after tracheotomy were similar in both groups, suggesting that the procedure itself and not its timing influenced the duration of mechanical ventilation and the length of stay in Intensive Care Unit of tracheotomized patients.
\end{abstract}

Key Words: Tracheotomy - Methods; Respiration, Artificial; Treatment Outcome; Intensive Care Units; Observational Study

\section{Introduction}

Maintaining patent airway is often of vital importance for successful treatment of intensive care unit (ICU) patients ${ }^{1}$. Tracheotomy is a very common procedure performed in ICU patients who require prolonged mechanical ventilation ${ }^{2}$. It has several advantages over prolonged endotracheal intubation, including lower airway resistance, facilitated weaning from mechanical ventilation, improved patient comfort and their ability to communicate, lesser

Correspondence to: Tihana Magdic Turkovic, MD, Department of Anesthesiology and Intensive Care, Sestre milosrdnice University Hospital Center, Vinogradska c. 29, HR-10000 Zagreb, Croatia E-mail: tihana.magdic.turkovic@gmail.com

Received February 28, 2015, accepted: September 9, 2015 need for sedation drug administration, possibility of oral feeding and easier nursing care ${ }^{3}$. Because of its advantages over surgical tracheotomy, percutaneous tracheotomy is performed more frequently ${ }^{2,4}$. Despite decades of experience in tracheotomy, there still exists a controversy over its ideal timing ${ }^{5}$. Analysis of a large number of studies showed considerable variation in the opinions on optimal tracheotomy timing due to its influence on mechanical ventilation duration, the length of ICU stay, the frequency of ventilator-associated pneumonia (VAP) and mortality rates ${ }^{2,6-10}$. Some studies showed benefits of early tracheotomy, whereas others failed to do so. The literature also fails to bring any clear consensus about what should be considered early tracheostomy, the timing to be found in various definitions thereby ranging from 2 to even 10 days fol- 
lowing endotracheal intubation and mechanical ventilation initiation or ICU admission ${ }^{11}$, so that optimal tracheotomy timing remains controversial.

The aim of our study was to compare the impact of early and late tracheotomy in terms of their ability to reduce mechanical ventilation duration and the length of ICU stay, as well as VAP frequency and mortality rates in percutaneously tracheotomized surgical ICU patients.

\section{Patients and Methods}

The study was conducted in a 15-bed surgical and neurosurgical ICU of the Department of Anesthesiology and Intensive Care, Sestre milosrdnice University Hospital Centre, Zagreb, Croatia. The study was approved by the Hospital Board of Ethics (E.P. number: 35-1/09). Retrospective data were collected from September 2009 to March 2013. Because of the retrospective and observational design of the study, an informed consent was unnecessary.

Only patients undergoing percutaneous tracheotomy during the study period were eligible for the study. Patients were excluded from the study if they were younger than 18 years, or had previous or emergency tracheotomy.

Study patients were divided into those tracheotomized during the first 7 days following ICU admission ('early tracheotomy') and those tracheotomized 8 or more days after ICU admission ('late tracheotomy'). Percutaneous tracheotomies were performed by the ICU physicians by the patient bedside using the Griggs method. Reasons for performing tracheotomy were respiratory (predicted mechanical ventilation longer than 10 days, weaning difficulties, neuromuscular weakness/the need for more than 10-12 times daily suctioning) or neurological (Glasgow Coma Score lower than 9).

Ventilator-associated pneumonia is defined as a type of nosocomial pneumonia occurring more than 48 hours after intubation and mechanical ventilation ${ }^{12}$. The presence of VAP was defined using the simplified Modified Pulmonary Infection Score (CPIS) ${ }^{13}$.

All patients were fed enterally using a nasogastric tube (in most patients starting from day 2 of ICU stay), received systemic stress ulcer prophylaxis (ranitidine or proton pump inhibitors) and were kept in a semi-recumbent position during their ICU stay.
The inter-group comparison was made based on the patient status at ICU admission and during ICU stay, and characteristics of surviving patients.

\section{Statistical analysis}

Demographic and clinical data were presented as median and $25^{\text {th }}$ and $75^{\text {th }}$ interquartile range, or number (\%). Continuous variables were compared using Student's t-test for independent samples, while categorical variables were compared using $\chi^{2}$-test. $P$ values $<0.05$ were considered statistically significant. Difference in the frequency of VAP between the groups was calculated using Fisher's exact test. All statistical analyses were performed using MedCalc 9.5.1.0 (MedCalc Software, Mariakerke, Belgium).

\section{Results}

During the study period, 5,071 adult patients were admitted to our ICU. One hundred and fortytwo $(2.8 \%)$ of these patients underwent percutaneous tracheotomy. Of the 142 percutaneously tracheotomized patients, 78 were early tracheotomized and 64 late tracheotomized. Tracheotomy was performed at a median of 6 (5-6) days after ICU admission in the early tracheotomy group and at a median of 12 (916) days after ICU admission in the late tracheotomy group. Table 1 shows the characteristics of VAP patients established at ICU admission. Patient groups did not differ significantly according to age, gender, main reasons for ICU admission and prevalence of the majority of comorbidities, with the exception of chronic obstructive pulmonary disease (COPD). COPD was more prevalent in the late tracheotomy group compared to the early tracheotomy group. The Simplified Acute Physiology Score II (SAPS II) and Acute Physiology and Chronic Health Evaluation II (APACHE II) scores (taken during the first 24 hours following ICU admission) were higher in the early tracheotomy group as compared with the late tracheotomy group. The proportion of the main reasons for ICU admission did not differ between the groups. The most frequent reason for ICU admission in both groups was postoperative care.

Table 2 shows the characteristics of VAP patients observed during ICU stay. In the late tracheotomy group, the main reason for mechanical ventilation 
was of respiratory nature, while in patients with early tracheotomy the reason for mechanical ventilation was mainly neurological or the need of sedation. During the study period, antibiotic treatment was more frequently required in the late tracheotomy group, whereas sedation was more often needed in the early tracheotomy group. Duration of mechanical ventilation before tracheotomy was longer in the late tracheotomy group. The early tracheotomy group was subjected to tracheotomy mainly for neurological reasons, whereas in the late tracheotomy group the reasons were mostly of respiratory nature. VAP developed in 60 (42\%) patients, 27 (45\%) of them with early tracheotomy and $33(55 \%)$ with late tracheotomy $(\mathrm{p}=0.060)$. There were no between-group differences in the frequency of VAP after tracheotomy. After tracheotomy, six of $78(8 \%)$ patients in the early tracheotomy group and six of $64(9 \%)$ patients in the late tracheotomy group developed VAP ( $\mathrm{p}=0.768)$.

The overall ICU mortality among percutaneously tracheotomized patients was 29\% (41/142). Mortality was not different between two groups $(27 \%$ vs. $31 \%, \mathrm{p}=0.704)$. In the surviving patients, total duration of mechanical ventilation and the number of days in ICU were shorter in the early tracheotomy group compared with the late tracheotomy group. Duration of mechanical ventilation and the number of days in ICU before tracheotomy were shorter in patients with early tracheotomy than in those with late tracheotomy, but after placement of the tracheotomy, both groups were weaned off mechanical ventilation and discharged from the ICU after similar periods. The groups did not differ significantly according to SAPS II at discharge (Table 3).

Table 1. Patient characteristics at ICU admission

\begin{tabular}{|c|c|c|c|}
\hline & $\begin{array}{c}\text { Early tracheotomy } \\
\mathrm{N}=78\end{array}$ & $\begin{array}{c}\text { Late tracheotomy } \\
\mathrm{N}=64\end{array}$ & $\mathrm{p}$-value \\
\hline Age (years) & $62(47-74)$ & $66(56-78)$ & 0.170 \\
\hline \multicolumn{4}{|l|}{ Gender } \\
\hline Male & $52(67)$ & $46(72)$ & \multirow{2}{*}{0.627} \\
\hline Female & $26(33)$ & $18(28)$ & \\
\hline APACHE II score & $16(13-20)$ & $14(11-17)$ & 0.038 \\
\hline SAPS II & $46(34-57)$ & $36(27-48)$ & 0.022 \\
\hline \multicolumn{4}{|c|}{ Main reason for ICU admission } \\
\hline Medical $^{*}$ & $4(5)$ & $3(5)$ & \multirow{3}{*}{0.374} \\
\hline Trauma without surgery & $12(15)$ & $5(8)$ & \\
\hline Surgery & $62(80)$ & $56(88)$ & \\
\hline \multicolumn{4}{|l|}{ Comorbidities } \\
\hline Diabetes mellitus & $8(10)$ & $10(16)$ & 0.482 \\
\hline Malignant disease & $3(4)$ & $6(9)$ & 0.318 \\
\hline COPD & $2(3)$ & $10(16)$ & 0.013 \\
\hline Chronic cardiac disease & $10(13)$ & $17(27)$ & 0.063 \\
\hline Kidney failure & $2(3)$ & $6(9)$ & 0.166 \\
\hline Hypertension & $27(35)$ & $29(45)$ & 0.261 \\
\hline Alcoholism & $13(17)$ & $12(19)$ & 0.918 \\
\hline Smoking & $15(19)$ & $15(23)$ & 0.686 \\
\hline Emergency admission & $72(92)$ & $55(86)$ & 0.340 \\
\hline
\end{tabular}

Results are presented as median $\left(25^{\text {th }}-75^{\text {th }}\right.$ interquartile range), or as number (\%); VAP $=$ ventilatorassociated pneumonia; T = (percutaneous) tracheotomy; SAPS II = Simplified Acute Physiology Score II; APACHE II = Acute Physiology and Chronic Health Evaluation II; COPD = chronic obstructive pulmonary disease; ICU = Intensive Care Unit; " acute respiratory failure, sepsis, state after resuscitation 
Table 2. Patient characteristics during ICU stay

\begin{tabular}{|c|c|c|c|}
\hline & $\begin{array}{l}\text { Early tracheotomy } \\
\mathrm{N}=78\end{array}$ & $\begin{array}{l}\text { Late tracheotomy } \\
\qquad \mathrm{N}=64\end{array}$ & p-value \\
\hline \multicolumn{4}{|l|}{ Reason for MV } \\
\hline Respiratory* & $19(24)$ & $36(56)$ & \multirow{3}{*}{$<0.001$} \\
\hline Neurological $^{\dagger}$ & $27(35)$ & $13(20)$ & \\
\hline Need for sedation & $32(41)$ & $15(24)$ & \\
\hline \multicolumn{4}{|l|}{ Treatment } \\
\hline Antibiotics & $59(76)$ & $60(94)$ & 0.007 \\
\hline Glucocorticoids & $17(22)$ & $19(30)$ & 0.428 \\
\hline Sedation & $49(63)$ & $24(38)$ & 0.003 \\
\hline Dialysis & $2(3)$ & $3(5)$ & 0.822 \\
\hline Transfusion & $66(85)$ & $55(86)$ & 0.987 \\
\hline Number of days on MV before $T$ & $5(3-6)$ & $8(7-10)$ & $<0.001$ \\
\hline \multicolumn{4}{|l|}{ Reason for $T$} \\
\hline Respiratory ${ }^{\#}$ & $11(14)$ & $33(52)$ & \multirow{2}{*}{$<0.001$} \\
\hline Neurological $^{*+}$ & $67(86)$ & $31(48)$ & \\
\hline \multicolumn{4}{|l|}{ Frequency of VAP } \\
\hline VAP before $T+$ after $T$ & $27(35)$ & $33(52)$ & 0.060 \\
\hline VAP before $T$ & $21(27)$ & $27(42)$ & 0.074 \\
\hline VAP after $\mathrm{T}$ & $6(8)$ & $6(9)$ & 0.768 \\
\hline
\end{tabular}

Results are presented as median (25th-75th interquartile range), or as number (\%). VAP = ventilatorassociated pneumonia; $\mathrm{T}$ = (percutaneous) tracheotomy; $\mathrm{MV}=$ mechanical ventilation; $\mathrm{ICU}=$ Intensive Care Unit; *acute respiratory failure, neuromuscular weakness, ARDS; †GCS lower than 9; łpredicted long MV due to trauma or disease of the lung ( $>10$ days), weaning difficulties, neuromuscular weakness/ need for frequent suctioning ( $>10-12$ times daily); §GCS lower than 9; \#during first seven days after admission to ICU; **from day eight after admission to ICU

Table 3. Characteristics of surviving patients

\begin{tabular}{|lccc|}
\hline & $\begin{array}{c}\text { Early tracheotomy } \\
\mathrm{N}=78\end{array}$ & $\begin{array}{c}\text { Late tracheotomy } \\
\mathrm{N}=64\end{array}$ & $\mathrm{p}$-value \\
\hline Surviving patients & $57(73)$ & $44(69)$ & 0.704 \\
\hline Duration of MV (days) & & & \\
$\quad$ Before T & $5(3-6)$ & $8(7-10)$ & $<0.001$ \\
After T & $1(1-2)$ & $2(0-5)$ & 0.071 \\
Total & $6(4-7)$ & $11(7-14)$ & 0.002 \\
\hline Number of days in ICU & & & \\
Before T & $6(5-6)$ & $12(9-16)$ & $<0.001$ \\
After T & $8(5-15)$ & $8(4-17)$ & 0.164 \\
Total & $13(8-18)$ & $22(15-34)$ & $<0.001$ \\
\hline SAPS II at discharge & $28(20-41)$ & $26(18-35)$ & 0.252 \\
\hline
\end{tabular}

Results are presented as median (25th-75th interquartile range), or as number (\%). VAP = ventilatorassociated pneumonia; $\mathrm{T}=$ (percutaneous) tracheotomy; $\mathrm{MV}=$ mechanical ventilation; $\mathrm{ICU}=$ Intensive Care Unit; SAPS II = Simplified Acute Physiology Score II 


\section{Discussion}

Our study showed that, in surgical patients, early tracheotomy was associated with a reduction in mechanical ventilation duration and length of ICU stays, but had no effect on VAP frequency and mortality rates. In both groups, weaning patients from mechanical ventilation took place at a similar posttracheotomy time, suggesting that tracheotomy itself and not its timing was a critical factor responsible for the shorter mechanical ventilation and shorter length of ICU stay.

According to many recent prospective randomized studies, early tracheotomy seems to reduce the duration of mechanical ventilation and the length of ICU stay ${ }^{6,10,14-17}$. However, some of the studies failed to confirm this observation ${ }^{18-20}$. A few recent metaanalyses have also failed to confirm any favorable impact of early tracheotomy on mechanical ventilation duration and length of ICU stay ${ }^{3,5}$. The reason behind these discrepancies may lie in considerable differences in the definition of early versus late tracheotomy offered by various studies, defining early tracheotomy as one performed 2 to even 10 days following endotracheal intubation and mechanical ventilation initiation or ICU admission ${ }^{3}$. Also, many studies do not clearly state whether total duration of mechanical ventilation or just its post-tracheotomy duration was taken into account. For example, a prospective randomized study that included 419 patients has reported that tracheotomy performed 6 to 8 days following endotracheal intubation was associated with a reduced duration of mechanical ventilation as compared with that performed 8 days following endotracheal intubation. However, the duration of mechanical ventilation calculated within this study frame considered the randomization day as day 1 and took it from there, thereby neglecting the fact that both study groups were randomized at the same time ${ }^{10}$. According to our results, early tracheotomy decreases total mechanical ventilation duration and total length of ICU stay, but not the duration of post-procedural mechanical ventilation or the length of post-procedural ICU stay, since no differences in this regard were seen between our study groups. It is only logical that early tracheotomy results in a shorter duration of pre-procedural mechanical ventilation, since the procedure itself was performed earlier in these patients, but the post-procedural duration of mechanical ventilation was shown to be similar in both groups. In both of our study groups, weaning from mechanical ventilation took place in a similar post-tracheotomy time, suggesting that tracheotomy itself and not its timing was a critical factor accountable for the shorter duration of mechanical ventilation. Our results are in discordance with the results of some observational studies, which have reported that tracheotomies performed earlier may be associated with quicker weaning from mechanical ventilation ${ }^{8,21}$.

The study also showed that early tracheotomy was more likely to be performed in patients with higher APACHE II and SAPS II scores, showing that this procedure is generally performed in critical patients. However, these patients had similar mortality rates as compared to the late tracheotomy arm, which might lead to a conclusion that early tracheotomy may influence mortality rates in patients with higher APACHE II and SAPS II scores.

Chronic obstructive pulmonary disease was more common in the early as compared to the late tracheotomy group. Respiration-related reasons for the initiation of mechanical ventilation and tracheotomy performance were also more common in the same study group, suggesting that earlier tracheotomy with a possibly shorter duration of mechanical ventilation might be justified in these patients.

According to our results, there were no betweengroup differences in mortality rates. The effects of early tracheotomy on mortality rates varied across different studies $^{3,5}$, which might be attributed to differences in the inclusion criteria, definition of early tracheotomy, methods of percutaneous tracheotomy, underlying diseases, severity of illness, comorbidities and individual study quality. Most of the meta-analyses that embraced prospective studies dealing with our study topic, have suggested that early tracheotomy does not significantly reduce mortality rates $3,5,22,23$. In contrast, one recent meta-analysis found lower overall mortality rates in early tracheotomized patients, but the analysis in question included observational studies only ${ }^{24}$. In accordance with our results, almost all recent prospective randomized studies indicated that early tracheotomy did not influence mortality rates ${ }^{2,10,14-17,20,25}$. Only 3 prospective randomized studies showed that patients who had early tracheotomy had lower mortality rates than 
those having late tracheotomy $y^{6,18,19}$. However, the beneficial outcomes of early tracheotomy declared by two of these three studies should be interpreted with caution because of the small sample size ${ }^{18,19}$. The third one, on the other hand, included only critical patients with APACHE II score above 25 and the expected mortality rate of $50 \%+{ }^{6}$.

The impact of early tracheotomy on VAP frequency is not clear. By reducing breathing efforts, preventing micro-aspiration of oral secretions and improving lung mechanics, early tracheotomy may facilitate weaning from mechanical ventilation, thereby reducing the time at risk of developing $\mathrm{VAP}^{10}$. Early tracheotomy may also result in greater patient comfort and sedation drug avoidance associated with prolonged mechanical ventilation duration as the main risk factor for VAP development ${ }^{3}$. In our ICU patients, early tracheotomy reduced the relative risk of post-tracheotomy VAP by $28 \%$ (relative risk $0.82,95 \%$ confidence interval 0.27 2.4). Namely, in 142 percutaneously tracheotomized patients, post-tracheotomy VAP developed in six of $78(8 \%)$ early tracheotomized patients and in six of 64 (9\%) late tracheotomized patients, but the risk reduction did not reach statistical significance $(\mathrm{p}=0.768)$. In some recent studies, early tracheotomy was associated with lower VAP incidence, but, of note, the cumulative, not the post-tracheotomy VAP incidence, was taken into account ${ }^{6,15-17,26}$. Our results pertaining to the VAP frequency are in accordance with the study by Clech et al., who also took only VAPs occurring after tracheotomy into account ${ }^{27}$. Some other trials that set VAP as their endpoint obtained similar results too ${ }^{2,10,19,25}$. According to many studies, antibiotic treatment and sedation are the risk factors facilitating VAP development ${ }^{26}$. In our study, the early tracheotomy arm was represented by less frequent antibiotic and more frequent sedation drug administration, but the VAP frequency established in both of our study groups remained the same.

Our study had several limitations. It was conducted retrospectively at a single ICU centre. Another limitation was the heterogeneity of our study patients and a low number of those subjected to percutaneous tracheotomy.

In conclusion, the present study indicated that early tracheotomy was associated with a reduced duration of mechanical ventilation and reduced length of ICU stay, but was unable to reduce VAP frequency and ICU mortality. The reason behind the shorter $\mathrm{du}^{-}$ ration of mechanical ventilation and shorter length of ICU stay in the early tracheotomy arm was the shorter duration of mechanical ventilation carried out prior to tracheotomy, while the duration of mechanical ventilation and the length of ICU stay after tracheotomy were similar in both groups, suggesting that the procedure itself and not its timing influenced the duration of mechanical ventilation and the length of ICU stay of tracheotomized patients.

\section{References}

1. Suljević I, Beharić S, Surković I. Complications in preserving the airway in intensive care unit patients. Acta Clin Croat. 2012;51(3):519-24.

2. Blot F, Similowski T, Trouillet JL, Chardon P, Korach JM,Costa MA, et al. Early tracheotomy versus prolonged endotracheal intubation in unselected severely ill ICU patients. Intensive Care Med. 2008;34(10):1779-87. doi: 10.1007/ s00134-008-1195-4.

3. Durbin CG Jr. Tracheostomy: why, when, and how? Respir Care. 2010;55(8):1056-68.

4. Beltrame F, Zussino M, Martinez B, Dibartolomeo S, Saltarini $\mathrm{M}$, Vetrugno $\mathrm{L}$, et al. Percutaneous versus surgical bedside tracheostomy in the intensive care unit: a cohort study. Minerva Anestesiol. 2008;74(10):529-35.

5. Wang F, Wu YP, Bo LL, Lou JS, Zhu JL, Chen F, et al. The timing of tracheotomy in critically ill patients undergoing mechanical ventilation: a systematic review and meta-analysis of randomized controlled trials. Chest. 2011;140(6): 1456-65. doi: 10.1007/s10096-013-1978-6.

6. Rumbak MJ, Newton M, Truncale T, Schwartz SW, Adams JW, Hazard PB. A prospective, randomized, study comparing early percutaneous dilational tracheotomy to prolonged translaryngeal intubation (delayed tracheotomy) in critically ill medical patients. Crit Care Med. 2004;32(8):1689-94.

7. Frutos-Vivar F, Esteban A, Apezteguía C, Anzueto A, Nightingale P, González M, et al. International Mechanical Ventilation Study Group Outcome of mechanically ventilated patients who require a tracheostomy. Crit Care Med. 2005;33(2):290-8.

8. Freeman BD, Isabella K, Lin N, Buchman T. A meta-analysis of prospective trials comparing percutaneous and surgical tracheostomy in critically ill patients. Chest. 2000;118(5):1412-8.

9. Combes A, Figliolini C, Trouillet JL, Kassis N, Wolff M, Gibert C, et al. Incidence and outcome of polymicrobial ventilator-associated pneumonia. Chest. 2002;121(5):1618-23.

10. Terragni PP, Antonelli M, Fumagalli R, Faggiano C, Berardino $\mathrm{M}$, Pallavicini $\mathrm{FB}$, et al. Early vs late tracheotomy 
for prevention of pneumonia in mechanically ventilated adult ICU patients: a randomized controlled trial. JAMA. 2010;303(15):1483-9. doi: 10.1001/jama.2010.447.

11. Jeon YT, Hwang JW, Lim YJ, Lee SY, Woo KI, Park HP. Effect of tracheostomy timing on clinical outcome in neurosurgical patients: early versus late tracheostomy. J Neurosurg Anesthesiol. 2014;26(1):22-6. doi: 10.1097/ ANA.0b013e31829770a0

12. Hunter JD. Ventilator associated pneumonia. Postgrad Med J. 2006;82(965):172-8.

13. Singh N, Rogers P, Atwood CW, Wagener MM, YU VL. Short-course empiric antibiotic therapy for patients with pulmonary infiltrates in the intensive care unit. Am J Respir Crit Care Med. 2000;162(2):505-11.

14. Arabi Y, Haddad S, Shirawi N, Al Shimemeri A. Early tracheostomy in intensive care trauma patients improves resource utilization: a cohort study and literature review. Crit Care. 2004;8(5):347-52.

15. Gandia-Martinez F, Martinez-Gil I, Andaluz-Ojeda D, Bobillo de Lamo F, Parra-Morais L, Diez-Gutierrez F. Analysis of early tracheostomy and its impact on development of pneumonia, use of resources and mortality in neurocritically ill patients. Neurocirugia. 2010;21(3):211-21.

16. Koch T, Hecker B, Hecker A, Brenck F, Preuß M, Schmelzer $\mathrm{T}$, et al. Early tracheostomy decreases ventilation time but has no impact on mortality of intensive care patients: a randomized study. Langenbecks Arch Surg. 2012;397(6):1001-8. doi: 10.1007/s00423-011-0873-9.

17. Zheng Y, Sui F, Chen XK, Zhang GC, Wang XW, Zhao S, et al. Early versus late percutaneous dilational tracheostomy in critically ill patients anticipated requiring prolonged mechanical ventilation. Chin Med J (Engl). 2012;125(11):1925-30.

18. Barquist ES, Amortegui J, Hallal A, Giannotti G, Whinney $\mathrm{R}$, Alzamel $\mathrm{H}$, et al. Tracheostomy in ventilator dependent trauma patients: a prospective, randomized intention-to-treat study. J Trauma. 2006;60(1):91-7.
19. Saffle JR, Morris SE, Edelman L. Early tracheostomy does not improve outcome in burn patients. J Burn Care Rehabil. 2002;23(6):431-8.

20. Trouillet JL, Luyt CE, Guiguet M, Ouattara A, Vaissier E, Makri R, et al. Early percutaneous tracheotomy versus prolonged intubation of mechanically ventilated patients after cardiac surgery: a randomized trial. Ann Intern Med. 2011;154(6):373-83. doi: 10.7326/0003-4819-154-6201103150-00002.

21. Scales DC, Thiruchelvam D, Kiss A, Redelmeier DA. The effect of tracheostomy timing during critical illness on longterm survival. Crit Care Med. 2008;36(9):2547-57. doi: 10.1097/CCM.0b013e31818444a5

22. Dunham CM, Ransom KJ. Assessment of early tracheostomy in trauma patients: a systematic review and meta-analysis. Am Surg. 2006;72(3):276-81.

23. Liu X, Wang HC, Xing YW, He YL, Zhang ZF, Wang $T$. The effect of early and late tracheotomy on outcomes in patients: a systematic review and cumulative meta-analysis. Otolaryngol Head Neck Surg. 2014;151(6):916-22. doi: 10.1177/0194599814552415.

24. Shan L, Hao P, Xu F, Chen YG. Benefits of early tracheotomy: a meta-analysis based on 6 observational studies. Respir Care. 2013;58(11):1856-62. doi: 10.4187/respcare.02413.

25. Bouderka MA, Fakhir B, Bouaggad A, Hmamouchi B, Hamoudi D, Harti A. Early tracheostomy versus prolonged endotracheal intubation in severe head injury. J Trauma. 2004;57(2):251-4.

26. Nseir S, Di Pompeo C, Jozefowicz E, Cavestri B, Brisson $\mathrm{H}$, Nyunga $\mathrm{M}$, et al. Relationship between tracheotomy and ventilator-associated pneumonia: a case control study. Eur Respir J. 2007;30(2):314-20.

27. Clec'h C, Alberti C, Vincent F, Garrouste-Orgeas M, de Lassence A, Toledano D, et al. Tracheostomy does not improve the outcome of patients requiring prolonged mechanical ventilation: a propensity analysis. Crit Care Med. 2007;35(1):132-8. 
Sažetak

\section{USPOREDBA RANE I KASNE PERKUTANE TRAHEOTOMIJE U KRITIČNO BOLESNIH: RETROSPEKTIVNA OPSERVACIJSKA STUDIJA U JEDNOM CENTRU}

\section{T. Magdić Turković, A. Lukić i M. Perić}

Traheotomija je vrlo čest postupak koji se izvodi kod bolesnika koji zahtijevaju produženu mehaničku ventilaciju. Unatoč desetljećima iskustva u izvođenju traheotomije još uvijek postoje dileme o idealnom vremenu izvođenja. Cilj ovoga istraživanja je bio usporedba rane i kasne traheotomije s obzirom na njihov utjecaj na trajanje mehaničke ventilacije i duljinu boravka u Jedinici intenzivnog liječenja, kao i na učestalost pojave ventilacijske pneumonije i smrtnost među traheotomiranim bolesnicima. Istraživanje je provedeno u 15-krevetnoj Jedinici intenzivnog liječenja Odjela za anesteziologiju, reanimatologiju i intenzivno liječenje u Kliničkom bolničkom centru "Sestre milosrdnice", Zagreb, Hrvatska. Podaci su skupljani retrospektivno od rujna 2009. do ožujka 2013. godine. U istraživanje su bili uključeni samo bolesnici perkutano traheotomirani tijekom navedenog razdoblja. Rezultati ovoga istraživanja ukazuju na to da rana traheotomija skraćuje trajanje mehaničke ventilacije i duljinu boravka u Jedinici intezivnog liječenja, dok na učestalost ventilacijske pneumonije i smrtnost nema utjecaja. Razlog kraćeg trajanja mehaničke ventilacije i kraćeg boravka u Jedinici intezivnog liječenja je kraće trajanje mehaničke ventilacije prije izvođenja traheotomije, dok je trajanje mehaničke ventilacije nakon traheotomije bilo slično u obje skupine, što upućuje na zaključak da sam postupak traheotomije, a ne vrijeme izvođenja utječe na trajanje mehaničke ventilacije i duljinu boravka u Jedinici intenzivnog liječenja.

Ključne riječi: Traheotomija-metode; Respiracija, umjetna; Ishod liječenja; Jedinice intezivnog liječenja; Opservacijska studija 